Tyndale Bulletin 69.1 (2018) 1-24

\title{
COVENANT, TYPOLOGY, AND THE STORY OF JOSEPH
}

\author{
Samuel Emadi \\ (scemadi@gmail.com)
}

\begin{abstract}
Summary
Critical scholars traditionally assert that the Joseph story (Genesis 3750) does not develop any of the covenantal themes prominent in Genesis 1-36. By considering Joseph's relationship to the kingship, seed, land, and blessing promises of the Abrahamic covenant, this article concludes that the Joseph story provides a significant development of the Abrahamic covenant. Joseph is an anticipatory fulfilment of the covenant and thus provides literary and redemptivehistorical resolution to the Genesis narrative. Joseph also points forward to a more complete fulfilment of the patriarchal hopes expressed in the Abrahamic covenant. These observations provide evidence from within Genesis itself that the author intends Joseph to be read typologically, anticipating God's eschatological work through the Messiah.
\end{abstract}

\section{Introduction}

The author ${ }^{1}$ of Genesis affords Joseph more time in the narrative foreground than any other character. This is a striking fact, given the significance of Genesis' other main characters, Adam, Noah, and the patriarchs Abraham, Isaac, and Jacob. This prominence is even more striking considering the apparent insignificance of Joseph in the rest of the OT. The name 'Joseph' is mentioned just fifty-seven times in the

\footnotetext{
${ }^{1}$ I refer to the 'author' though I see no reason to doubt Scripture's own testimony that Moses is the author of Genesis, albeit edited later. See, for instance, the argument for Mosaic authorship made by Duane Garrett in Rethinking Genesis (Grand Rapids: Baker, 1991).
} 
OT, excluding Genesis. Five of these occurrences refer to other individuals (Num. 13:17; Ezek. 10:42; Neh. 12:14; 1 Chr. 25:2, 9) while another forty-five refer to Joseph's eponymous tribe. Thus the OT explicitly refers to Joseph only seven times outside of Genesis (Exod. 1:5, 6, 8; 13:19; Josh. 34:35; Ps. 105:17; 1 Chr. 2:2; 5:1).

The prominence of the Joseph story in Genesis and the few references to him thereafter pose a particular challenge to the biblical theologian whose aim is to read any portion of Scripture in the context of the entire Christian canon. How should interpreters read the Joseph narrative in the context of the entire Genesis narrative and ultimately in canonical context? These questions are intimately associated with another, narrower, biblical-theological question: is Joseph a type of the Messiah? While others have asked whether later Scriptures confirm or deny Joseph's typological character, the question remains whether the Joseph narrative itself indicates that Joseph's life ought to be read as a pattern of God's future saving activity.

Regrettably, modern enquiries into Genesis $37-50$ have neglected this dimension of the Joseph story. In short, these modern critical treatments of the Joseph story, essentially concentrating on the sourcedivisions (and thus internal incoherence) of the story, disengaged Genesis 37-50 from its place in the story of Genesis in particular and in the OT in general. ${ }^{2}$ Even as scholars challenged source-critical approaches and reasserted the narrative's synthetic unity by virtue of a thoughtful redactor(s), the Joseph story was still seen as an isolated literary composition without any significant literary, theological, or biblical theological connection to the rest of Genesis. Redford's comments are typical among historical-critical approaches:

The theological outlook of the writer of Gen. 37-50 is different from that of the Patriarchal narrator. He does not mention the Covenant or the Promise, ubiquitous in the earlier chapters of Genesis. He is not interested in supplying the reader with comment on matters theological, as the Patriarchal author was. ${ }^{3}$

2 For an overview of critical interpretation of the Joseph story see C. Paap, Die Josephsgeschichte, Genesis 37-50: Bestimmungen ihrer literarischen Gattung in der zweiten Hälfte des 20. Jahrhunderts (Europäische Hochschulschriften, 23, Theologie, 534; Frankfurt am Main: Peter Lang, 1995); Raymond de Hoop, Genesis 49 in Its Literary and Historical Context (Leiden: Brill, 1998): 366-450.

3 Donald B. Redford, A Study of the Biblical Story of Joseph (vol. XX; VTSup; Leiden: Brill, 1970): 247. 
Since scholars saw the Joseph narrative as disconnected from Genesis, they had long abandoned any attempt to interpret it within redemptivehistorical context. ${ }^{4}$ As Brevard Childs noted, amidst the raging debates of historical-critical concerns (such as Gunkel's designation of the Joseph story as a novella or von Rad's argument that the wisdom tradition gave birth to the story of Joseph):

there was little or no attention given to the canonical questions. What is the shape of the final chapters and what is their function within the book as a whole? ... If Joseph is not the bearer of the promise in the same way as his forefathers, what then is his role in Genesis? ${ }^{5}$

This article aims to provide at least a partial answer to the question Childs asked nearly forty years ago. Joseph's redemptive-historical and typological significance is only visible in light of his relationship to the Abrahamic covenant. My thesis is that the author depicts Joseph as the first instantiation of the fulfilment of the Abrahamic promises and in so doing casts Joseph in a Messianic light. More fully, I will argue that Joseph provides literary and redemptive-historical resolution to the Genesis narrative and also points forward to a more complete fulfilment of the patriarchal hopes expressed in the Abrahamic covenant. Joseph, in part, fulfils the promises to Abraham, showing the type of work God will do in the future. In other words, the story of Joseph represents an anticipatory fulfilment of the Abrahamic covenant. To demonstrate this thesis, I will consider Joseph's relationship to the covenantal themes of kingship, seed, land, and blessing.

\section{Joseph and Kingship}

\subsection{Joseph: Beloved Son and Servant King}

The kingship theme in Genesis begins as early as the creation narrative, which establishes God's royal prerogatives over his creation. As several scholars have demonstrated, Yahweh commissions Adam to

4 T. Desmond Alexander concurs in 'The Regal Dimension of the תולדות־יעקב: Recovering the Literary Context of Genesis 37-50' in Reading the Law: Studies in Honour of Gordon J. Wenham, ed. J. G. McConville and K. Möller (New York: T\&T Clark, 2007): 198.

5 Brevard S. Childs, Introduction to the Old Testament as Scripture (Philadelphia: Fortress Press, 1979): 156. 
share in the royal task, and the author depicts Adam in Genesis 1-2 as a priest-king. ' 'God not only reigns over people', observes Treat: 'he also reigns through them.' 7

After Genesis 3, as God acts to reclaim humanity and restore his kingdom in creation, the restoration of human vice regency is vital to that end. Thus, the hope for royal seed is woven into the fabric of Abraham's covenant promises. Through Abraham, God will not only restore the land, fruitfulness, and blessing of Eden but will also restore human vice regency. For this reason, the transfer of covenant promises to succeeding generations often includes and is intimately tied to the promise of future royalty (Gen. 17:6; cf. 17:16; also 22:17b-18). ${ }^{8}$

The Joseph story continues to develop this kingship theme. ${ }^{9}$ Strikingly, Joseph's introduction in Genesis 37 bears a number of royal features. His dreams, which become his defining characteristic (37:1920 ), portend a regal future. In the first dream, Joseph's sheaf is exalted above those of his brothers and even receives obeisance from them. Such bowing (חוה) suggests an action done for a royal figure, which is exactly how the brothers interpret the dream. Their incredulous

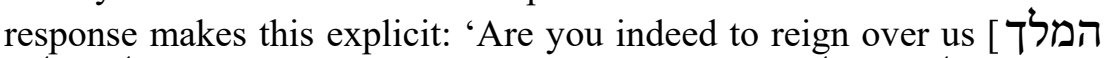
אם משול תמשל בנו] or are you indeed to rule over us מתמלך עלינו (37:8)]'? Further, משל מלד and מלד occur in the same context only three other times in the OT, each instance clearly denoting royalty (Judg. 9:2, 6, 8; Jer. 33:21, 26; 2 Chr. 9:26, 30).

Joseph's second dream continues in the same vein. In this instance the sun, moon, and eleven stars bow down before Joseph. While these celestial bodies represent Joseph's family, the imagery itself is suggestive. Only the king of creation would have the obeisance of the cosmos. Joseph again uses the word חוה (Gen. 37:9), as does Jacob

6 Stephen G. Dempster, Dominion and Dynasty: A Biblical Theology of the Hebrew Bible (NSBT 15; Downers Grove, Illinois: InterVarsity Press, 2003): 55-75; Peter Gentry and Stephen Wellum, Kingdom through Covenant (Wheaton, Illinois: Crossway Books, 2012): 177-221.

7 Jeremy Treat, The Crucified King: Atonement and Kingdom in Biblical and Systematic Theology (Grand Rapids: Zondervan, 2014): 55.

8 Daniel S. Diffey, 'The Royal Promise in Genesis: The Often Underestimated Importance of Genesis 17:6, 17:16 and 35:11', TynBul 62, no. 2 (2011): 313-16. T. Desmond Alexander, 'Further Observations on the Term "Seed" in Genesis', TynBul 48, no. 2 (1997): 363-67. T. Desmond Alexander, 'Royal Expectations in Genesis to Kings', TynBul 49, no. 2 (1998): 191-212.

9 T. Desmond Alexander has also explored the concept of royalty in Genesis 37-50 in his essay 'The Regal Dimension of the תולדות־יעקב', 196-212. 
when he rebukes Joseph for his dreams (להשתחות לך ארצה [Gen. 37:10]).

While the dream sequences contain the most explicit royal imagery, other features of chapter 37 also seem to foreshadow Joseph's future royal status. Joseph's famous 'coat of many colours' (כתנת פסים [37:3]) may signify some sort of royal garb. ${ }^{10}$ While the translation of is notoriously difficult, the OT mentions this type of clothing elsewhere only once: when describing the 'long dress with sleeves' - the typical garb of the virgin daughters of the royal family worn by Tamar (2 Sam. 13:18). As Wilson notes, the dream and the robes represent the same reality of Joseph's future royal pre-eminence. 'As far as the brothers are concerned, the robe and the dream are one, for their reaction to both is the hatred of Joseph. The robe will carry the meaning of, and will symbolize the dreams for the rest of the chapter.' 11

Genesis 37:3 may reveal even more about Joseph's leadership in the family. Jacob loves Joseph more than his other sons because Joseph is a 'son of old age to him' (בן־זקנים הוא לו). While some commentators understand this to mean that Joseph was beloved because he was born late in Jacob's life, this explanation for Jacob's favouritism is odd. Why, then, would Jacob's favouritism not extend to Joseph's younger brother, Benjamin, who was also a son of the favoured wife, Rachel, and later identified as ילד זקנים, the 'child of [Jacob's] old age' (Gen. 44:20)?

Lowenthal posits that in this instance בן connotes a 'word of quality' or expresses a 'characteristic' rather than genealogy. ${ }^{12}$ Joseph is, thus, a 'sage' or, as Lowenthal suggests, 'a born leader'.13 Lowenthal's solution, however, is problematic. The phrase בן plural זקן occurs only two other places in the OT, both in reference to Isaac (Gen. 21:2, 7, both בן לזקניו). Lowenthal's notion that this phrase represents a wise son or 'a born leader' works for 17-year-old Joseph, but could not be applied to Isaac, who is only a few days old in Genesis 21. A more likely interpretation is that בן־זקנים typecasts Joseph with

10 Walter Brueggemann, Genesis (Interpretation; Louisville: Westminster John Knox, 1982): 300; Bruce K. Waltke, Genesis: A Commentary (Grand Rapids: Zondervan, 2001): 500 .

11 Lindsay Wilson, Joseph Wise and Otherwise: The Intersection of Wisdom and Covenant in Genesis 37-50 (Carlisle: Paternoster Press, 2004): 67, also 69-70.

12 Eric Lowenthal, The Joseph Narrative in Genesis (New York: KTAV, 1973): 167.

13 Lowenthal, The Joseph Narrative, 168. 
an Isaac-like identity. ${ }^{14}$ Joseph appears on the scene much like the first son of promise, and, as such, the covenantal and dynastic expectations for Isaac (and Jacob) are now linked to him.

Whether all or just some of these features associate Joseph with royalty, the dream sequences rather unambiguously portray him as the potential first royal seed of Abraham. ${ }^{15}$ As Alexander notes, 'kingship is the 'dominant motif' of the dreams. ${ }^{16}$ This characterisation is surely suggestive. As Alexander comments:

In light of the royal expectations found prior to Gen. 37, it is hardly a coincidence that the plot of the Joseph story should rely so heavily on the theme of royalty for its development. Since the narratives in Gen. 12-36 associate kingship with the patriarchs and their descendants, the manner of Joseph's introduction in Gen. 37 is significant. ${ }^{17}$

Readers of Genesis have awaited - prophetically, typologically, and by covenant promise - the arrival of a royal seed through the line of Abraham. Now, in the opening verses of the final toledot section, the introduction of Joseph heightens that anticipation. Readers in touch with the royal theme cannot help but question 'Are you the one who is to come, or should we expect another?'

The narrative of Joseph's descent into slavery and prison continue to hint, and then finally affirm, his regal destiny. In hindsight, readers can see that, in God's providence, the further Joseph descends in social rank, the closer he moves to the royal court. Though in prison, he moves one step closer to the palace, as Potiphar appoints him custodian of the chief cupbearer and baker of the 'king of Egypt' $(40: 1,4)$.

Finally, Pharaoh exalts Joseph to his right hand, including him in the royal court. Joseph may not be king, but the author describes him with royal attributes. Joseph's dreams come to fruition when his brothers 'bow down' (חוה) before him three times (42:4 and 43:26, 28), matching the three uses of הוה in the dream sequence in Genesis 37:7, 9-10. The brothers who once scoffed at the notion that Joseph would 'rule' (משל) over them (Gen. 37:8) report to their father that

\footnotetext{
14 I am indebted to Aubrey Sequeira for this insight.

15 Alexander rightly notes that while these features of Joseph's introduction in Genesis 37:2-4 do not 'establish Joseph's royal credentials' with the same sort of certainty as do the dreams, 'due consideration should be given to them in the light of the acknowledged artistry of the Joseph Story' (Alexander, 'The Regal Dimension of the 202, (תולדות־יעקב).

16 Alexander, 'Royal Expectations in Genesis to Kings', 206.

17 Alexander, 'The Regal Dimension of the תולדות־יעקב', 201.
} 
Joseph is alive and 'ruling' (משל) over Egypt. Joseph even describes himself as a 'father to Pharaoh, lord [אדון] of all his house, and ruler [משל] over all the land of Egypt' (Gen. 45:8; cf. 45:9, 26), a description that 'appears to be overly stated', perhaps in order to cast Joseph as a regal figure. ${ }^{18}$

Joseph's royal status is the first hope for resolution to an eschatological expectation burgeoning since Genesis 1 and now mediated through the promises of the Abrahamic covenant (Gen. 17:6; cf. 17:16). Alexander correctly notes 'When viewed as part of the book of Genesis as a whole, Joseph's regal connections take on a deeper significance. His dreams and their fulfilment come in the context of a family tradition that has royal expectations embedded within it.' 19

Joseph's rise to royalty, therefore, is not merely evidence of God's vindication or approbation of his faithfulness. It is the first tangible evidence of God's unswerving commitment to restore human vice regency through a son of Abraham. ${ }^{20}$ God promised Abraham a dynasty, a royal seed. Joseph is the first of that seed, a new Adam mediating God's blessings to the nations - a beloved son and a servant king.

\subsection{Joseph and Judah: Present and Future Royal Seed}

Given the contours of Genesis thus far, readers might expect that the identity of the royal line is now clear: it is Joseph and his progeny. Yet a final plot twist shatters those expectations. At the end of his life, Jacob blesses his children by prophesying concerning the 'last days' (Gen. 49:1) and identifies Judah as the father of the royal line in Genesis 49:10.

While readers might have assumed Joseph would be the father of Abraham's royal line, the revelation that Judah is the line of Israel's royal seed is not entirely unexpected. Judah is more than a supporting actor in the Joseph story. Literary interplay between Judah and Joseph emerges as early as Genesis 37 and the subsequent juxtaposition of their stories in Genesis 38 (Judah's story) and Genesis 39-41 (Joseph's story). These chapters contain numerous linguistic parallels relating the

\footnotetext{
18 Alexander, 'Royal Expectations in Genesis to Kings', 206.

19 Alexander, 'The Regal Dimension of the 200 תולדות'יעקב',

20 We see this same commitment in restatements of the royal promise such as in Genesis 27:27-29. Joseph, however, is the first historical manifestation of a seed of Abraham taking a prominent place in a royal court.
} 
characters to one another. ${ }^{21}$ This juxtaposition continues throughout the story, climaxing in the Messianic prophecy in Genesis 49:8: 'Judah, your brothers shall praise you; your hand shall be on the neck of your enemies; your father's sons shall bow down before you.'

Jacob depicts the coming Judahite with imagery that closely resembles the life of Joseph. Judah's brothers will praise him and even 'bow down' (חוה) before him - the same word used three times of the brothers' obeisance to Joseph in the dreams (Gen. 37:7, 9, 10) and another three times when they actually bow before him (Gen. 42:4; $43: 26,28$ ). Indeed, the image of eleven brothers 'bowing' to their royal sibling in Genesis 49:8 reads like a summary of the preceding Joseph story. This similarity is deliberate. Joseph is a 'narrative prefiguration' of Judah's seed. ${ }^{22}$ In other words, the first frame of reference the original audience would use to interpret the phrase would be the story of Joseph. Should those readers ask what the coming Judahite will look like, they have an answer provided in Genesis 49:8 - he will look like Joseph.

Sailhamer, one of the few scholars to comment on the connection between this prophecy and the preceding narrative, summarises it well:

It is difficult not to see in this statement an intentional allusion to the dream of Joseph (37:10) in which his father's sons would come to bow down before him. In other words, that which was to happen to Joseph, and did happen in the course of the narrative (e.g., 42:6), has been picked up by way of this image and transferred to the future of the house of Judah. That which happened to Joseph is portrayed as a picture of that which would happen to Judah 'in the last days' (49:1). ${ }^{23}$

The association of Joseph and Judah is particularly fecund for a biblical theology of the Joseph narrative. Even if, as some scholars claim, Genesis 49:8-12 is not messianic, the point remains the same. ${ }^{24}$ The life of the future royal seed of Israel is patterned on the life of Joseph. Joseph is the type of king Israel will see again.

21 See Samuel Emadi, 'Covenant, Typology, and the Story of Joseph: A LiteraryCanonical Examination of Genesis 37-50' (Ph.D. dissertation, The Southern Baptist Theological Seminary, 2016): 74-78.

22 I have adopted the language of 'narrative prefiguration' from Michael Shepherd, Daniel in the Context of the Hebrew Bible (SBLSBL 123; New York: Peter Lang, 2009): 13.

23 John Sailhamer, The Pentateuch as Narrative: A Biblical-Theological Commentary (Grand Rapids: Zondervan, 1992): 235.

24 Westermann argues for a non-messianic reading in Genesis 37-50, trans. John Scullion (Minneapolis: Augsburg, 1982): 232. 
By drawing a typological line from Joseph to the future king from Judah, the author explicitly folds the Joseph narrative into Israel's larger story, which will culminate with the Messiah. This association retrospectively informs our reading of the story. To ensure that readers see Joseph as a royal figure with eschatological significance, the author now makes that point plainly. The account of Joseph is not an end in itself. It is a pattern for God's work in the future.

In short, Jacob's prophecy is the most explicit evidence from Genesis that Joseph should be read typologically - his life is a pattern of things to come. Genesis 49:8 crystallises his biblical-theological significance. This text effectively 'eschatologises' the preceding Joseph narrative. The king from the line of Judah will be Joseph redivivus the Joseph of 'the last days'.

\section{Joseph and the Promise of Seed}

Like the theme of kingship, the theme of 'seed' (i.e. numerous offspring) extends as far back as the creation account. In the Edenic state, reproduction was the central component needed for fulfilling God's eschatological programme (Gen. 1:28). After the fall, however, the proliferation of 'kingdom' seed can only come through the redeemed line of promise and, even then, only through great difficulty. After Genesis 3, obstacles litter the path of seed-bearing. Even more, as Genesis 3:15 intimates, serpentine assaults will imperil the seed's survival. For God to fulfil his promises the covenant seed must not only prosper but be preserved through many dangers.

Adam's commission to 'be fruitful and multiply' (פרו ורבו) passes through Noah (Gen. 9:1, 7) to the patriarchs Abraham (Gen. 12:2; 17:2, $6,8,16 ; 22: 18)$, Isaac (Gen. 26:3-4, 24), and Jacob (28:3-4, 14; 35:1112). As we might expect, the command to produce numerous offspring is transposed into a promise of the Abrahamic covenant (Gen. 12:2; 17:6; etc.). Whereas Yahweh once said 'be fruitful and multiply', in the Abrahamic covenant he says 'I will multiply you exceedingly ... I will make you exceedingly fruitful' (Gen. 17:2, 6).

Once again, the story of Joseph changes the melody of Genesis from the music of promise to that of fulfilment. Through the ministry of Joseph, the Abrahamic hope of nationhood is first realised. In this sense, Joseph catalyses God's creation of a new humanity. 
The theme of preservation of the seed marks Joseph's ministry to his family and characterises Joseph's own self-understanding. In Genesis 45:5-8, a rare moment of theological interpretation from within the story, Joseph informs his brothers (and readers) of the redemptivehistorical significance of the events of his life. The primary theme of these verses is God's superintending providence over all human affairs, a theme that will reappear more concisely in Genesis 50:20. Emphasising divine providence, Joseph declares that God sent him to preserve life (Gen. 45:5), and then he adds that God sent him, more specifically, to preserve a 'remnant' (Gen. 45:7).

Joseph's affirmation in verse 7 that God sent him to 'preserve a remnant (שארית)' and to 'keep alive ... survivors (פליטה)' is particularly interesting given how these words are 'freighted with theological significance' 25 in the Prophets, especially when used in tandem (Isa. 10:20; 37:32; cf. 2 Kgs 19:31; Joel 2:32). Additionally, 'remnant' and 'survivor' in Genesis 45:7 signify that God saves the covenant community from destruction as a sign of future hope for the nation - essentially the same idea found in the Prophets. In both the exilic era and in Genesis, Yahweh preserves a 'remnant of Israel and ... survivors of the house of Jacob' (Isa. 10:20). The apparent connection to the prophetic corpus is so arresting that critical scholars view it as evidence of post-exilic theology's influence on the Joseph story. ${ }^{26}$ Of course, the evidence is insufficient to posit that prophetic remnant theology emerged out of Genesis 45:7 or that Isaiah intends an allusion to this passage in Isaiah 10:20 or 37:32. But given the verbal and conceptual similarities, it is not out of the question that Genesis 45 could have easily influenced prophetic writing about God preserving a remnant.

God's intention to preserve a remnant or seed is a major theme throughout Genesis. God has preserved the seed through child-bearing in the face of violence (Gen. 4:1-26), through an ark in the face of judgement (Gen. 6:9-9:29), through divine intervention in the face of foreign corruption (Gen. 12:10-20), and even through sacrifice in the face of certain death (Gen. 22:1-19). Now, through Joseph, God protects the covenant line in the face of famine, a perennial enemy endangering the covenant line throughout Genesis (Gen. 3:17-19;

25 Victor Hamilton, The Book of Genesis: Chapters 18-50 (NICOT; Grand Rapids: Eerdmans, 1995): 576. This is the only instance of שארית in the Pentateuch.

26 Westermann, Genesis 37-50, 145. 
$12: 10 ; 26: 1 ; 42: 1-2)$. Joseph's use of 'remnant' and 'survivor' in Genesis 45:7 continues this idea and is, in part, an embryonic manifestation of the OT's remnant theology - a subtle foreshadowing of a theme more prominently developed in later revelation. Also, God's purpose 'to preserve life' (v. 5 [למחיה]) and to 'keep alive' (v. 7 [ולהחיות) may correlate Joseph to Noah, the archetypal seedpreserver in Genesis. As Wenham notes, "to preserve" (life) is a key phrase in the flood story $(6: 19-20$; cf. 7:3; 50:20), implying that Joseph is like Noah, an agent in the divine saving plan'. ${ }^{27}$

The following chapters continue to focus on the preservation and proliferation of the seed. At the beginning of Genesis 46, God recommits himself to his covenantal seed promise. He assures Jacob about the decision to go into Egypt (Gen. 46:3) and indicates that 'there' - in Egypt(!) - God will begin to fulfil his promise to make Jacob's line 'into a great nation' (גוי גדול). This phrasing recalls the promise God made when he first spoke to Abraham in Genesis 12:2. Alter's conclusion is right: 'both the language and the action of this whole scene are framed as an emphatic recapitulation of the earlier Patriarchal tales'. ${ }^{28}$

The rest of Genesis 46 is an outworking of God's promise to make Jacob a 'great nation'. Verses 5-7 establish this point generally, while verses 8-27 accomplish the same task in greater detail. Almost each line in the chapter makes some reference to the seed's preservation and proliferation. Verses 5-7 indicate that Jacob is accompanied to Egypt by his sons, daughters, and their families - indeed, 'all his offspring' (vv. 6, 7). Verses 8-27 focus our attention even more on this offspring. As Smith notes, 'In Genesis 46:3, God promised to make Jacob a "great nation". The list of Genesis 46:8-27 demonstrates that before Jacob even reached Egypt, the fulfillment of that promise was already well under way. ${ }^{29}$

27 Gordon Wenham, Genesis 16-50 (Dallas: Word Books, 1994): 428; see also Kenneth Mathews, Genesis 11:27-50:26 (NAC; Nashville: Broadman \& Holman, 2005): 813.

28 Robert Alter, Genesis: Translation and Commentary (New York: Norton, 1996): 273.

29 Bryan Smith, 'The Presentation of Judah in Genesis 37-50 and Its Implications for the Narrative's Structural and Thematic Unity' (Ph.D. dissertation, Bob Jones University, 2002): 283. 
The colophon at the end of the genealogy totals Jacob's descendants at 'seventy' (Gen. 46:27) - a highly suggestive annotation. As Dempster notes,

remarkably, this list includes seventy members, the same number as the nations enumerated in the Table of Nations (Gen. 10), which were eventually dispersed across the earth. Here is Abraham's new humanity, a new "Table of Nations," called into being to restore the nations to the fulfillment of the divine purpose. ${ }^{30}$

Yahweh is both preserving (Gen. 45:5-8) and multiplying Israel. Jacob's descendants are emerging as a nation. Under Joseph, the promise of offspring begins to be fulfilled. As Wilson rightly explains:

The fact that [the genealogy] immediately follows verses 1-7, which were bursting with echoes of the patriarchal promises, suggests that this element in the narrative is being reinforced. The implied reader has been immersed in Joseph's rise to power, and wise use of it, coupled with his scheme to achieve reconciliation with his brothers. Now the editor is drawing back from this specific focus in order to show the larger picture of God's purposes for the world through his covenant people. ${ }^{31}$

These observations show how Joseph relates to Genesis' larger story of creation and covenant. Covenantal and patriarchal themes emerge quite prominently in Joseph's story, but only after the reconciliation between Joseph and his brothers. This order is significant. Fraternal conflict has plagued the covenant family and endangered the seed promise as far back as Cain and Abel. Joseph's reconciliation with his brothers, however, triggers an advance in covenant history. God, by his gracious providence, undoes the fraternal hostility impeding the success of his promises. As a result, God begins to fulfil his promises and the covenant seed flourishes. This narrative progression 'makes it clear that more is at stake than simply the fate of a wandering family' ${ }^{32}$ In Joseph God reverses the status quo of violence against the covenant line. The reconciliation of the family is a demonstration that God is reversing the curse, turning evil in on itself, and advancing his cause in the world - as a result, the covenant seed blossoms.

This focus on the seed promise intensifies in Genesis 47:27. The preceding narrative records the devastation of the famine (Gen. 47:13-

30 Dempster, Dominion and Dynasty, 89. Also Sailhamer, The Pentateuch as Narrative, 225; Matthew Thomas, These Are the Generations: Identity, Covenant, and the Toledot Formula, LHBOTS (New York: T\&T Clark, 2011): 109.

31 Wilson, Joseph Wise and Otherwise, 186.

32 Wilson, Joseph Wise and Otherwise, 187. 
26). Yet, even in the midst of famine, God brings life and prosperity to Israel through Joseph. Counter-intuitively, the Israelites increase even as the curses of Genesis 3 press against them in full force. Joseph's planning and God's blessing cause Israel to prosper.

Significantly, the author describes the state of the Israelites in Goshen with words reminiscent of the Garden of Eden: 'thus Israel settled in the land of Egypt, in the land of Goshen. And they gained possessions in it, and were fruitful and multiplied greatly [יפרו וירבו מאד]' (Gen. 47:27). Up to this point, the word pair 'fruitful and multiply' (פרה ורבה) has either been imperative or promissory. In other words, God has either commanded people to be fruitful and multiply (Gen. 1:28; 9:1, 7; 35:11) or promised that they will do so $(16: 10 ; 17: 2,6 ; 22: 17 ; 26: 4,24)$. But now, for the very first time, fruitfulness and multiplication is a reality - an indicative. Furthermore, under Joseph's reign, Abraham's seed not only flourishes, but does so exceedingly (מאד).

What began as a command to Adam transformed into a promise to Abraham and has now become a reality. In Genesis 47:27, the Israelites participate in the long-awaited fulfilment of the commission originally given to Adam in Genesis 1:28 and in the promises restated to Abraham. Through the mediation and leadership of Joseph - the royal seed - the people of God flourish into a new humanity. The Adamic commission to multiply image bearers begins not in the garden, but in exile, and this because of the reign and provision of the rejected royal son. ${ }^{33}$

and in Genesis

Gen. 1:28

Imperative

Gen. 9:1

Imperative

Gen. 9:7

Imperative

Gen. 16:10

(רבה only)

Promise

Gen. 17:2, 6

Promise

Gen. 22:17

(רבה only)

Promise

Gen. 26:4

(רבה only)

Promise

Gen. 26:24

(רבה only)

Promise

Gen. 28:3

Benediction

33 See similar observations by Timothy J. Stone, 'Joseph in the Likeness of Adam: Narrative Echoes of the Fall' in Genesis and Christian Theology, ed. Nathan MacDonald, Mark Elliot, and Grant Macaskill (Grand Rapids: Eerdmans, 2012): 70. 
Gen. 35:11

Imperative

Gen. $48: 4$

Promise

Gen. 47:27

Indicative

Other narrative features show that Genesis 1:28 is only partially fulfilled in Genesis 47:27 - it is an anticipatory fulfilment. For instance, God restates his seed promise to Jacob at Luz in the next chapter (Gen. 48:4), revealing that something more is still expected. Nevertheless, the commission 'be fruitful and multiply' bookends Genesis. In Genesis 1:28 we see the initial command, and in Genesis 47:27 we find its fulfilment, though presented such that readers expect more to come. Kaminski, who traces the development of Genesis 1:28 throughout Genesis, summarises the evidence well: 'Genesis 47:27 may be seen, therefore, as the first explicit statement that the primaeval commands to "be fruitful and multiply" (Gen. 1:28; 9:1; cf. Gen. 35:11) have been executed. Thus we may conclude that Gen. 47:27 marks the initial fulfillment of the promise of increase and of the primaeval commands. ${ }^{34}$

Joseph's crucial role in fulfilling the seed promise is confirmed by later biblical authors. Psalm 105, depending on Joseph's interpretation of his own story in Genesis 45:4-8, records that Yahweh 'sent' Joseph ahead of the Israelites (Ps. 105:17), presumably to preserve them through the famine (Ps. 105:16, 20-22). As a result, 'Israel came to Egypt ... and the LORD made his people very fruitful [ויפר] and made them stronger than their foes' (Ps. 105:23-24). The Psalmist thus identifies Joseph as Yahweh's agent, preserving and prospering the seed of Jacob in the midst of famine. Joseph's preserving influence on Israel is also highlighted in Exodus 1:8, when a new Pharaoh oppresses Israel because he 'did not know Joseph'. Even the memory of Joseph in the court of Egypt prospered Israel. Once that memory faded, the blessing and prosperity Joseph mediated to his family vanished.

\section{Joseph and the Promise of Land}

The land theme in Genesis begins (like kingship and seed) in the very first chapters of Genesis with the creation of Eden. Eden is described as

34 Carol Kaminski, From Noah to Israel: Realization of the Primaeval Blessing After the Flood (JSOTSup 413; London: T\&T Clark, 2004): 123. 
a garden-sanctuary. ${ }^{35}$ God commissions Adam to carry out his royalpriestly duties in Eden - an archetypal temple (cf. Ezek. 28:13's designation of Eden as the 'garden of God'). Thus, Adam's kingship not only includes the notion of 'reign' but also 'realm'. Adam's dominion includes cultivating and caring for the land, protecting it from evil, and expanding the borders of God's dwelling.

The fall, however, disrupts the relationship between the king and his realm. God drives Adam from the garden and establishes an angelic sentinel to bar him from returning (Gen. 3:24). God works to undo this discord in the Abrahamic covenant. He promises Abraham and his descendants the land of Canaan as an everlasting possession (Gen. $15: 7,18-21 ; 17: 8)$. But this promise means more than mere real estate. The exile from Eden is being overturned. Canaan represents restoration to Eden and access, once again, to life in God's presence.

For the most part the patriarchs live out their time within Canaan's boundaries (though acquiring only enough land for their burial plots). This situation abruptly changes in the Joseph story, when famine forces Jacob's sons to go to Egypt, as it had with Abraham three generations prior (Gen. 12:10-20). The migration of the covenant family to Egypt seems to be a retrogression in redemptive history. In fact, as Hamilton points out, Genesis is bookended by two major literary sections characterised by life outside the promised land. ${ }^{36}$ Both famine and fraternal strife drive the covenant family away from Canaan, displacing and thus apparently returning them to a pre-Genesis 12 state of life 'east of Eden'. This migration reveals that threats to the seed also endanger the land promise.

Due to the Egyptian setting of the story, Joseph's relevance to the land promise is not immediately clear. As Wilson observes, 'the promise of the land does not loom large in the Joseph narrative, since the story takes not only Joseph, but also Jacob and his other sons, out of Canaan and into Egypt'. ${ }^{37}$ Yet, as with the seed theme, the reconciliation episode in Genesis 45 results in a resurfacing of the land theme. Explicit references to the land promise, for example, appear in Genesis $46: 4$ and 48:4. In the first instance, Yahweh promises to bring

35 G. K. Beale, The Temple and the Church's Mission: A Biblical Theology of the Dwelling Place of God, NSBT 17 (Downers Grove: InterVarsity Press, 2004): 66-79.

36 Victor Hamilton, The Book of Genesis: Chapters 1-17 (NICOT; Grand Rapids: Eerdmans, 1990): 10.

37 Wilson, Joseph Wise and Otherwise, 225. 
Jacob back to Canaan. In the second, Jacob recounts Yahweh's covenant promise to him at Luz (Gen. 35:9-15) as a way of transferring those covenant blessings to his children, which now include Joseph's own Ephraim and Manasseh.

Furthermore, the land theme is prominent in the final scene of the narrative, no doubt to transition to the story of the Exodus. The author, it appears, subtly identifies Joseph with the fulfilment of the land promise in the death narratives of Jacob and Joseph. As Lunn has argued, Genesis 49:29-50:26 is a concentric pattern that places the final words of Jacob and Joseph in parallel, with Jacob's funeral at the centre - surprising narrative progression given the prominence of Joseph in the story thus far. ${ }^{38}$

\section{Concentric structure of Genesis 49:29-50:26}

A The last words and death of Jacob (49:29-50:3) - monologue

B Joseph's appeal to Pharaoh (50:4-6) - dialogue

C The funeral of Jacob (50:7-14) - narrative

B' The brother's appeal to Joseph (50:15-21) - dialogue

A' The last words and death of Joseph (50:22-26) - monologue

As others have noted, describes probably highlights Jacob's burial (the centre of the chiasm) for its typological significance. The removal of Jacob's body from Egypt foreshadows the Exodus - an 'acted prophecy' of the nation's future deliverance. ${ }^{39}$ Just as the beginning of the patriarchal narratives foreshadow the exodus with Abraham's journey to and from Egypt (Gen. 12), ${ }^{40}$ so now the end of the patriarchal narratives foreshadow the journey to the promised land with Jacob's removal. These two 'exodus episodes' form an inclusio around the entire patriarchal history. ${ }^{41}$

38 For a complete accounting of the linguistic evidence, see Nicholas Lunn, 'The Last Words of Jacob and Joseph: A Rhetorico-Structural Analysis of Genesis 49:29-33 and 50:24-26', TynBul 59, no. 2 (2008): 164-66.

39 Wenham, Genesis 16-50, 51; Lunn, 'The Last Words of Jacob and Joseph', 17478; Sailhamer, The Pentateuch as Narrative, 239.

40 Sailhamer, The Pentateuch as Narrative, 142; Lunn, 'The Last Words of Jacob and Joseph', 174-78; Gordon J. Wenham, Genesis 1-15 (WBC; Dallas: Word Books, 1987): 291-192.

41 See Lunn, 'The Last Words of Jacob and Joseph', 178 for a defence of this notion. 
This structure indirectly associates Joseph with the fulfilment of the Abrahamic land promise. The symmetrical pattern places Jacob's and Joseph's final wishes in parallel (A and A'). Both men ask to be buried in the promised land (Gen. 49:29; 50:25). As a result, upon death, Jacob (Israel) undergoes his own exodus to Canaan. The implication is that Joseph's death anticipates the same thing for the nation at large. Just as the death of Jacob led to an exodus from Egypt to the place of inheritance, so also Joseph's death is a harbinger of the real Exodus to come. Joseph's own last words highlight this point. 'God will surely come to your aid', he tells his brothers, 'and take you up out of this land to the land he promised on oath to Abraham, Isaac, and Jacob' (Gen. 50:24b, 25b; cf. Heb. 11:22).

God uses Joseph to fulfil the other features of the Abrahamic covenant (kingship, seed, blessing). Joseph's role in securing the land is not as obvious. Yet, given that his story takes place almost entirely in Egypt and that he lives there until his death, the parallel between Jacob's and Joseph's deaths and the resulting 'exodus' may be the author's way of connecting the life of Joseph with the fulfilment of the land promise. Joseph's dying words look forward to life in the promised land. His death signals hope for a national exodus from Egypt and the fulfilment of the land promise.

\section{Joseph and Blessing to the Nations}

Blessing, as Wellum and Gentry note, is most fundamentally 'connected with life'. ${ }^{42}$ Blessing characterises the fertility and vitality of the garden and is associated in Genesis 1:28 with the commission to 'be fruitful and multiply' (Gen. 1:28). Indeed, the entire creation project culminates in the 'blessed' seventh day, a foretaste of the blessing Adam was meant to experience in the eschaton (Gen. 2:3).

The fall shatters the Edenic state of blessing. Creation becomes characterised by the infertility and death of the curse (Gen. 3:14-19). Again, God establishes the Abrahamic covenant in response to the corruption and decay of the curse. God's call of Abraham in Genesis $12: 1-3$ is bathed in the language of blessing, using the word 'bless' five times in response to the fivefold use of 'curse' in Genesis 1-11. God

42 Gentry and Wellum, Kingdom through Covenant, 241. 
will bless Abraham (Gen. 12:2) and thus begin to undo the curses of Genesis 3.

Yet Abraham is more than a recipient of blessing - he is a conduit. $\mathrm{He}$ is blessed to be a blessing (Gen. 12:3). Through Abraham, the families of the earth (משפחת), last seen in the table of nations (Gen. 10:5: 18, 20, 31, 32), will also receive life. This 'blessing to the nations' is shown throughout the patriarchal accounts as those outside Abraham's immediate family benefit from their positive relationship with him or his children (cf. Gen. 18:16-33; 20:14, 17).

Genesis 39:2-3 provides the first explicit mention of covenant blessing in the Joseph story. Yahweh is 'with Joseph', causing him to excel in his administration of Potiphar's house. The same phrase is repeated even when Joseph lands in prison: Yahweh is 'with Joseph', giving him favour with his superiors and success in his vocation (Gen. 39:21, 23).

These affirmations of divine presence are significant. Divine presence characterises God's covenant relationship with the Abrahamic family. Further, Yahweh's presence is the sine qua non of covenant fulfilment. Without Yahweh being 'with' the patriarchs, there is no hope of seeing the promise of seed and land come to fruition. After Yahweh's opposition to Judah in Genesis 38 (the only other time the narrator mentions Yahweh in the Joseph story), the prospects of seed and land appear to be on shaky ground. The re-affirmation of divine presence with Joseph re-establishes God's commitment to fulfil his promises and identifies Joseph as the conduit of those blessings. Like Isaac and Jacob before him, Joseph now, by virtue of God's presence, carries the hope for the fulfilment of God's promises.

In accord with the pattern established in Genesis 12:2-3, Joseph is blessed and a blessing. Potiphar appoints Joseph as a steward 'over his house' (על־ביתו) and as a result Yahweh blesses Potiphar 'for Joseph's sake' (Gen. 39:4-5). Even Arnold, who favours a minimalist approach to the relationship between Joseph and the patriarchal narratives, admits that here we find an 'allusion to the ancestral promises ... Yahweh blessed Potiphar's household because of Joseph, who has no personal abilities to bless others. ${ }^{, 43}$ Later we again find Joseph established 'over a house' (על ביתי) - the house of Pharaoh

43 Bill T. Arnold, Genesis (NCBC; Cambridge: Cambridge University Press, 2009): 331. Also Sailhamer, The Pentateuch as Narrative, 210-11. 
(Gen. 41:40). The result is the same: Joseph blesses the nations by providing grain during a 'severe famine', first for Egypt (Gen. 41:56) and then for 'all the earth' (Gen. 41:57).

After the reconciliation episode, blessings emerge as a prominent feature of the story. Indeed, the final chapters are largely characterised by three blessing episodes, as Jacob blesses Pharaoh (Gen. 47:7-10), Ephraim and Manasseh (Gen. 48), and finally his twelve sons (Gen. 49). The most striking of these is Jacob's blessing of Pharaoh. Just prior to this encounter Pharaoh treats the covenant family well, giving them the 'best of the land' and hiring them to care for the royal court's livestock (Gen. 47:6). Given narrative patterns thus far, and given God's promise to bless those who bless Israel, these events suggest that both Pharaoh and his nation will be blessed.

Genesis 47:7-10 narrates, with some emphasis, the giving of that blessing to Pharaoh. Old man Jacob is brought before Pharaoh and blesses him (Gen. 47:7). The narrative sequence is quite startling. Jacob, though a sojourner and the father of a small band of seventy, takes the initiative and blesses Pharaoh before Pharaoh even speaks to him. Ultimately, what the author portrays is a narrative outworking of the Genesis 12:3 promise. Through the family of Abraham, the nations of the earth are blessed. Dempster notes: 'there are not just two individuals meeting here, but two nations, one of them embryonic and the other the most powerful nation on earth'. ${ }^{44}$ Yet, in a shocking twist, Jacob twice blesses Pharaoh. Again, Dempster rightly notes, 'the irony is impossible to miss. The hope for the world comes from Israel and not from Egypt. Blessing comes from a decrepit and broken Israel and not from a dominant and strong Egypt.' 45 Joseph's role in this episode is indirect, but no less significant. Jacob is present only because of Joseph's administrative genius and favour with Pharaoh. In the context of Genesis 37-50, this account evinces a view of Joseph as the one who triggers the fulfilment - at least initially - of the Abrahamic promises.

In this light, the following account (Gen. 47:13-26) describing Joseph's agrarian reforms ought also to be interpreted as an outworking of Jacob's blessing to Pharaoh. As McKenzie notes, 'there is no other adequate explanation for the inclusion of an extensive account of

44 Dempster, Dominion and Dynasty, 89.

45 Dempster, Dominion and Dynasty, 89. 
Joseph's land reforms'. ${ }^{46}$ Given that blessing characterises Joseph's interactions with Pharaoh and with Egypt, and given the explicit blessing to Pharaoh in Genesis 47:7-10, it would seem far-fetched to interpret Joseph here as a corrupt 'tyrant' wielding power to oppress the less fortunate. ${ }^{47}$ More likely this narrative signals blessing to the nations along the lines of Genesis $12: 3 .{ }^{48}$ Contrary to the rather negative spin on these events by modern interpreters, the Egyptians themselves praised Joseph for employing his wisdom to save their lives (Gen. 47:25).

Ultimately, Joseph is both blessed and a blessing. He mediates blessing to the nations, bringing prosperity to Potiphar and Pharaoh's houses. Finally, Jacob (Israel) explicitly blesses Pharaoh and the nation he represents. As a result, through Joseph's wise administration, the Egyptians find life in the midst of the famine. Israel's purpose is coming to fruition. The covenant family, led by Joseph, both blesses and is blessed by the nations.

\section{Biblical-Theological Synthesis: Suffering, Glory, and the Promise-Keeping God}

Biblical theology seeks to authentically integrate the different themes and storylines of Scripture into a cohesive narrative according to Scripture's own interpretive schema and literary development. If Joseph is indeed a typological royal figure, how does this fact square with the other themes of the Joseph narrative and with the larger story of Genesis? More specifically, how does Joseph's anticipatory fulfilment of the covenant fit with other prominent themes in the Joseph story such as suffering or divine providence?

The author has intertwined the themes of suffering and covenant throughout Genesis. The Joseph story, the dénouement of Genesis, provides the most explicit juxtaposition of these two themes. Many commentators have observed that the entrance of sin in Genesis does not undo God's teleological purposes for creation - it just re-routes the

\footnotetext{
46 Brian Alexander McKenzie, 'Jacob's Blessing on Pharaoh: An Interpretation of Gen. 46:31-47:26', WTJ 45 (1983): 396.

47 Trevor Watt, 'Joseph's Dreams' in Jung and the Interpretation of the Bible, ed. David L. Miller (New York: Continuum, 1995): 68-69.

48 McKenzie, 'Jacob's Blessing on Pharaoh', 395-98.
} 
path to that end. ${ }^{49}$ As Treat argues, the transformation of the command 'be fruitful and multiply' (Gen. 1:28) into the patriarchal promise unites God's purposes in redemption with those of creation. Thus, the goal of establishing God's global kingdom remains, but because of the fall 'a new way of arriving at the consummation was introduced'. ${ }^{50}$

This 'new way' maintains the centrality of a king who mediates the reign and blessings of God, but it introduces the notion that this king will endure suffering on the path to the throne. Again, Treat observes, 'suffering will be a key ingredient in God's victorious plan of redeeming his people and their royal task'. This idea appears first in Genesis 3:15: the seed of the woman will engage in mortal combat with the seed of the serpent. The seed of the woman will emerge victorious, but wounded. His victory will come with a cost - a 'bruised heel' atop the 'bruised head' of the serpent.

As Alexander argues, Genesis traces the line of the seed of the woman through Noah to the Patriarchs. ${ }^{51}$ These seeds are royal, inheriting Adam's royal commission now in the form of covenant promises. Yet each of these seeds endures suffering on the path to enjoy God's blessing. Genesis 22 particularly highlights these themes. God commands Abraham to sacrifice his only son - the promised seed. Isaac's near-death experience 'echoes the suffering of the seed of the woman' and is nothing less than a narrative portrayal of death and resurrection. ${ }^{52}$ After God provides a substitutionary ram (with language that portends the Day of Atonement), he promises that Abraham's seed 'shall possess the gate of his enemies' (Gen. 22:17) - a promise of royal victory over the foes of Abraham's descendants. The portrait may be faint, but the elements of suffering, substitution, and royalty all converge in the Akedah. Isaac, the promised seed of Abraham, embodies the future generations. The offspring of Abraham will suffer like Isaac, but they are promised royal victory over their enemies and salvation by substitutionary sacrifice. Their story will play out like a riff on Genesis 22 - a story of death and resurrection.

49 See Treat's excellent discussion of this entire point in Treat, The Crucified King, 53-67.

50 Meredith Kline, The Structure of Biblical Authority (Grand Rapids: Eerdmans, 1972): 155.

51 Alexander, 'Genealogies, Seed and the Compositional Unity of Genesis'.

52 Treat, The Crucified King, 61. 
Continuing the twin drum beat of seed and suffering, Joseph rises to the highest seat in the land through the experience of suffering. If Genesis 22 shows that the suffering of the seed is akin to death and resurrection, the Joseph story clarifies that the 'death' of the seed comes at the hands of his own brothers. ${ }^{53}$ Thus the suffering of Joseph develops a pattern visible since Genesis 3:15 and in so doing sets expectations for the new Joseph to emerge from the line of Judah (Gen. 49:8).

Joseph's royal administration fulfils the expectations set earlier in Genesis. He uses his position to bless and forgive the same brothers who threw him in the pit. 'Joseph's ascension to royalty is characterized by suffering and his reign is exercised over his brothers with forgiveness. ${ }^{54}$ Joseph's story is the story of glory through suffering, exaltation through humiliation, the cross, and the crown.

What about the divine providence theme? While the author keeps Joseph centre stage in Genesis 37-50, the main actor is none other than Yahweh himself. The story is not just about how Joseph fulfils the Abrahamic promises, but about how Yahweh keeps his covenant and fulfils his promises through a rejected but royal seed. God's providence serves God's promises. The divine providence theme in Genesis 37-50 cannot be divorced from its covenantal context. The author does not highlight God's providence to make an abstract point about God's sovereignty. Instead, he emphasises that God's providence guarantees that God will fulfil his promises. The covenant is secure in the hands of the God who can sovereignly orchestrate the actions of evil men for his good purposes (Gen. 50:20).

Ciampa rightly summarises how all of this shapes expectations for the reader of Genesis.

That God will raise up a descendant of Abraham who will bring blessing to all the world, perhaps as God's own vice-regent reigning in the land promised to the patriarch, would be an easily imagined scenario, given

\footnotetext{
53 As Dempster notes, the Old Testament's conception of death and resurrection is much more dynamic than modern western notions. Stephen G. Dempster, 'From Slight Peg to Cornerstone to Capstone: The Resurrection of Christ on "The Third Day" According to the Scriptures', WTJ 76 (2014): 385. Also Mitchell Lloyd Chase, 'Resurrection Hope in Daniel 12:2: An Exercise in Biblical Theology' (Ph.D. dissertation, The Southern Baptist Theological Seminary, 2013); Mitchell Lloyd Chase, 'The Genesis of Resurrection Hope: Exploring Its Early Presence and Deep Roots', JETS 57, no. 3 (2014): 467-80.

54 Treat, The Crucified King, 62.
} 
what God had already done through Joseph while he was in a foreign land.' 55

The two apparent opposites of suffering and blessing merge in this single character. Joseph is both sufferer and saviour, the prisoner and the prince.

Joseph is the beloved son who suffers in exile before blessing the nations and being exalted. He is part of a pattern developed, at least in nascent form, in Genesis. The rest of the OT continues this trajectory as other characters (David, Daniel, Esther) repeat the pattern. Further, as Gathercole notes, this is the story of Israel itself.

A general pattern in the Old Testament [is that] God makes Israel as well as individuals go through exile, misery, and even death before displaying his glory through saving them. The overarching pattern of Israel's history - sin, exile, return - is one case in point. Within that larger framework, the life story of Joseph is another. ${ }^{56}$

Joseph's experience is Israel's experience. He is thus, first and foremost, a type of Israel. His experiences of suffering and exile are shared by his kin, and in many ways his righteousness and consequent covenant blessings exemplify what Israel ought to be in the world. If Joseph is indeed a type of the Messiah it is first because he is a type of the nation.

\section{Implications for a Canonical Understanding of the Joseph Narrative}

This study yields three important conclusions. Firstly, these observations illuminate the plot and literary character of Genesis as story. The Joseph story is not just the last item in Genesis, but the resolution of the Genesis story, albeit one that anticipates a greater resolution to come. Genesis takes readers on a journey from promise to fulfilment, from fratricide (Cain and Abel) to forgiveness (Joseph and his brothers), and from famine to feast.

Secondly, contrary to modern critical proposals, the Joseph story has strong connections to the preceding narratives. It develops the

55 Roy E. Ciampa, 'The History of Redemption' in Central Themes in Biblical Theology: Mapping Unity in Diversity, ed. Scott Hafemann and Paul R. House (Grand Rapids: Baker, 2007): 267.

56 Simon Gathercole, Defending Substitution: An Essay on Atonement in Paul (Grand Rapids: Baker, 2015): 60. 
covenantal storyline from Adam to Noah to the patriarchs. The full implications of the Joseph narrative are clear only in light of the literary and theological relationship between Genesis 1-36 and 37-50.

Thirdly, Genesis itself supplies textual warrant that Joseph is a type of the Messiah. If Joseph fulfils the Abrahamic hopes, he creates an expectation that other Joseph figures will do the same - though more completely - in the future. As a royal seed of Abraham, endowed with God's very presence (Gen. 39:2, 23), Joseph mediates blessing to the nations, preserves the offspring of Abraham, triggers the 'multiplication and fruitfulness' of Israel's seed, and is a harbinger of Israel's Exodus from Egypt and inheritance of Canaan. The author, through Jacob's prophecy, projects this Josephite pattern of covenantal fulfilment into the future by patterning Israel's 'last days' messianic king after the life of Joseph (Gen. 49:8). All of these elements contribute to our understanding of Joseph according his covenantal context, which in turn gives warrant for a typological reading of the Joseph story. 